\title{
Mixing Politics and Competence in Promotion Office on Local Government (A Study at Regency Gowa and Makassar City of South Sulawesi Province)
}

\author{
$1^{\text {st }}$ Muhammad Nur Yamin \\ Departement of State Administration \\ Faculty Of Social Science \\ Universitas Negeri Makassar \\ Makassar, Indonesia \\ Nuryamin@unm.ac.id
}

\author{
$2^{\text {nd }}$ Muhammad Guntur \\ Departement of State Administration \\ Faculty of Social Science \\ Universitas Negeri Makassar \\ Makassar, Indonesia \\ m.guntur@unm.ac.id
}

\begin{abstract}
This study aims at determining the political influence and influence of competence in the promotion at the local government bureaucracy. This research is quantitative, Data analysis techniques are multiple linear regression. Data collection techniques using questionnaires and interviews. The Respondents are 109 people of 305 people on structural officials in the scope of the Gowa Regency Government and the Makassar City government by using proportionate stratified random sampling technique. The research findings are the politics (X1) has a stronger influence than the competency (X2) in the promotion of local government bureaucracy, with the regression equation $\breve{Y}=0.518+0.511(\mathrm{X} 1)+0.420(\mathrm{X} 2)+\mathrm{e}$, the influence of political aspects in promotion is dominated by the element of power expansion and job distribution because both are the basis for strengthening the dominance of the leader. Regarding aspects of competence, elements of knowledge and skills are very dominant influences in the promotion of the Office, both of which become indicators of employee reliability and professionalism. The strong influence of the political aspect compared aspect of the influence of competency in promotions Office, because the interests of political officials for trying to maintain power and career officials trying to maintain position. The promotion system combines merit system and patronage system, which is expected to get officials who have high competence and high integrity, without ignoring demands to accommodate supporters during the election of political official in the regional government.
\end{abstract}

Keywords- Promotion, Politics And Competence, Local Government.

\section{INTRODUCTION}

Job promotion is done to support the achievement of organizational goals, someone promoted to occupy a position must consider the right man on the right place aspect. Filling in structural positions in the bureaucratic world is not a process that works in the immune room and vacuum, various factors may potentially influence the creation of ideal conditions for merit-based promotion of the system, including formal legal factors, political factors, nepotism, primordianism and patrimonial culture. Various empirical and practical studies show that in an organization that carries out tasks based on the bureaucratic system, the political aspects determine the behavior of the bureaucracy in making decisions related to who is eligible to be promoted to a position, especially leading the organization.[1]-[5] According to Wahiyuddin (2014) [1] The results show that any recruitment, appointment, removal and civil servants career development are not based on the competence principles but political considerations. Aftermath, structural leadership echelon II officials to follow the pattern of political leadership and officials decisions. According to Sugiharta (2012) [2] adverse effects of the implementation of the staffing management at the autonomous region, where the more arbitrarily in the placement of an employee without considering the competence and qualifications of education employees are concerned. The Weberian bureaucracy in practice still has a point of contact with political issues.

Every organization or institution must be able to place its human resources in the right position, namely placing them in a position in accordance with the qualifications of one's skills and achievements. According to Donald (2007) [3] the success of an organization is determined by individuals who have competence. Assessing individual competencies viewed from four sides, namely knowledge, skills, experience and attitudes of work mastery. The more employees have competence, the easier it is for the organization to carry out its vision and mission based on the ability of human resources to carry out basic tasks and functions to occupy an appropriate position based on the promotion. Competence has an influence on job promotion, as long as knowledge, skills, experience and attitudes become criteria in determining a person's ability to perform work skills, developing authority and work responsibilities, having superior commitment and work performance. Norman and Augusto (2006) [4].

The bureaucracy on the one hand is led by political officials as holders of the highest power, while on the other hand the bureaucracy in its structure has career officials. The pattern of relations between the two officials is termed executive ascendancy by Carino (2004) [5] where the bureaucracy is subordinated to politics, the position of political officials is higher than career officials and more dominant. this condition creates a political nuance so thick 
occurs in the process of filling structural positions in the bureaucracy for power. Azhari (2008) [6] executive acendency as a phenomenon where job seekers are aware of the legislative scenario putting their career career position in the grip of political officials who have control over organizational resources, including the scope of hegemony over the broad and strong authority of political officials through claims of prerogative rights. According to Juan and Juan there is a relationship between political aspects of promotion activities in an organization, the more politicized a bureaucracy is, the more comparative a person is appointed (promoted) politically.[6] This shows that determining one's promotion is influenced by political aspects as an element of appropriateness. The political aspect is the aspect of behavior in the bureaucracy that colors power, decision making, policy, and division of position with the right person appointed in developing skills, authority, responsibility, commitment and achievements for the organization Davis[7]]

The placement of a person in various concepts of organizational structure is colored by the content of interests not entirely based on purpose. According to Daft the area of organization as an arena for political play lies in structural change, coordination between departments, allocation of resources, and management succession.[8] Specifically management succession will involve the act of recruiting, promoting and rotating managers, and becoming a high-level political process for organizations when coalitions, alliances, and even bribes occur to fight for positions. The emergence of bureaucratic politicization is defined as the promotion of merit-based systems with political criteria Peters and Pierre, meaning that there are other criteria besides merit system, namely patron-client criteria, the interaction between two individuals (the patron with the client) which is reciprocal with exchanging resources owned by each party.[9] Patron has the resources in the form of power, position, material, and the client has the resources in the form of energy, support, and loyalty. In the practice of competency and political aspects, it cannot be separated, there are no organizations that do not need political steps, on the contrary there is no one hundred percent organization based on decisions on rationality. But the politicization of bureaucracy often has negative connotations. Peters and Pierre politicization of the bureaucracy will disrupt the workings of the employee coaching system which should be based on the principles of sound, rational, and lawful public sector management, because the appointment of officials is only based on the principle of likes and dislikes (like and dislike) in the context of the interests of power, not based on consideration of ability, capacity and work experience.[10] Placement of employees must look more at the suitability of competency in the field of expertise with jobs and positions in the bureaucracy.[11] Employee placement must follow the principle of "the right man in the right place and the right man in the right job". The promotion system is expected to get employees who have high competence and high integrity, so that they can carry out their duties well. On the other hand, patronage in mutations cannot be avoided because of demands to accommodate supporters in the regional head elections, therefore efforts to maintain both systems in the promotion of local government bureaucracy, namely aspects of competence in the merit system and political aspects in the patronage system without neglecting the vision and mission of the regional government.

\section{RESEARCH METHODS}

The location of the study was carried out at the Regional Government of Gowa Regency and the Local Government of Makassar City, using a quantitative approach as a facilitator to examine the attributes / components of low causes and the dominant high influence of the dimensions of political variables and dimensions of competency variables on promotion. Quantitative approach with the type of survey research according to the unit analysis homogeneity assumption, where each organization of the regional work unit (SKPD) has the same characteristics, although it is specific to each SKPD but there are similarities as a basis that influence the activities of organizational members. Data collection techniques are; Questionnaire, in the form of a list of questions about the reasons they were appointed as leaders to the officials who were made as respondents, and documentation, data of proposed consideration reports of prospective officials that had been made by the bapjakat team Regional Secretariat of Gowa Regency and Makassar City. The sample size of 109 officials was determined using the Krecjie table Sugiono. The sampling technique uses stratified random sampling based on echelon positions (II, III, and IV). Data analysis techniques using descriptive analysis and multiple regression statistical analysis to determine the effect of independent variables (competence and politics) on the dependent variable (promotion), $\mathrm{F}$ test is used to determine the effect of independent variables simultaneously on the dependent variable.

\section{RESULTS AND DISCUSSION}

The issue of official promotion is based on political aspects or aspects of competence in the bureaucracy seen in echelon II and III position recruitment systems in the local government. The right man on the right place is considered by someone to be promoted to occupy a position, it is very reasonable that employee competencies play an important role but the political aspect determines the bureaucracy in making decisions related to who is worthy of being promoted to lead the organization.

Table 1. Respondents' Responses to Competency and Political Variables in Position Promotion in 2017 Local Government Bureaucracy

\begin{tabular}{|c|r|r|r|r|r|r|}
\hline \multirow{2}{*}{ Indicator } & \multicolumn{2}{|c|}{ Primary } & \multicolumn{2}{c|}{ Medium } & \multicolumn{2}{c|}{ High } \\
\cline { 2 - 7 } & $\mathrm{F}$ & $\%$ & $\mathrm{~F}$ & $\%$ & $\mathrm{~F}$ & $\%$ \\
\hline $\begin{array}{c}\text { Competence } \\
\text { variable }\end{array}$ & & & & & & \\
\hline Knowledge & 9 & 8,26 & 31 & 28,44 & 69 & $\mathbf{6 3 , 3 0}$ \\
\hline Skill & 11 & 10,09 & 48 & 44,04 & 50 & $\mathbf{4 5 , 8 7}$ \\
\hline Work attitude & 9 & 8,26 & 59 & 54,13 & 41 & 37,61 \\
\hline Experience & 11 & 10,09 & 56 & 51,38 & 42 & 38,53 \\
\hline Political variable & & & & & & \\
\hline Authority & 8 & 7,34 & 38 & 34,86 & 63 & $\mathbf{5 7 , 8 0}$ \\
\hline Decision-making & 9 & 8,26 & 45 & 41,28 & 55 & 50,46 \\
\hline Policy & 34 & 31,19 & 43 & 39,45 & 32 & 29,36 \\
\hline Distribution & 3 & 2,75 & 32 & 29,36 & 74 & $\mathbf{6 7 , 8 9}$ \\
\hline
\end{tabular}

The dominant dimension in the politics aspect is colored by employees who are promoted to occupy positions based on the authority of the leadership and the distribution of 
positions controlled by the leadership, the employees who are promoted are placed according to the wishes of the leadership. Power is always present in the political process. Bureaucracy politicization occurs because of the interests of political officials to maintain power and career officials to maintain office. Thoha (2014) [14] aspects of the political situation also influence the placement decisions of officers in structural positions, these conditions emphasize that the bureaucracy in the region is still associated with patrimonial bureaucracy and authoritarian in promotion.[12] Executive Ascendency model, Carino explains the position of political officials tend to be very strong and even tend to suppress and influence the bureaucracy, political officials have great authority in determining positions in the bureaucracy.[13] [15] This means that political judgments are far more strategic in determining who is eligible to be promoted, so the more rational a person's choice to be promoted to occupy a position. In the era of regional autonomy, the regional head has a big role in creating politicization of the bureaucracy because the regional head has a set of authorities that can make civil servants inevitably have to submit to the regent / mayor, unless they are willing to bear the risk of their bureaucracy being hampered. The domination of political officials in determining career officials invites the efforts of employees to establish closeness with the authorities to determine their position in the existing staffing structure, related to the implementation of a series of promotion processes. Prefer in Vigoda Organizational politics as an activity that is used by a person to obtain, improve, use power and other resources to produce desired outcomes in situations of uncertainty or disagreement.[13]-[15]

Political aspects are understood as a dynamic process to influence the relevant bureaucratic outcomes. Motivation is to politicize the bureaucracy, first is patronage, where political promises are made and filled in as a tribute to political allies. Patronage appointments are distributed by the winners to those who assist in the election of regional heads. second is policy oriented, political officials can politicize career positions in order to gain greater control, staff with the personnel they choose, in this way, politicization becomes a means of directing executive policy Almendares. Decisions of politicization are taken, including officials politics wants to be able to control what the bureaucrats in the government do, and politicians also need civil servants who agree with the attitude of politicians (having the same attitude) and loyal individuals Peters and Pierre[16].

Promotion of employees occupying positions in terms of competence, dominant in the dimensions of knowledge and skills. Employees who are promoted are expected to have independence in their work and reliable and professional knowledge in their field of office. Competence influences job promotion, as long as knowledge is a criterion in determining a person's ability to perform work skills, developing authority and work responsibilities. The promotion process system of officials in the local government tends to see work experience, formal education, and training that is followed. The bureaucracy must continue to prioritize the principle of meritocracy in terms of promotion and mutation of its personnel.[17] The promotion system is expected to get employees who have high competence and high integrity, so they can carry out their duties well. The placement of employees must look more at the suitability of the field of expertise with jobs and positions in the bureaucracy.[18] Employee placement must follow the principle of "the right man in the right place and the right man in the right job", so that they can place employees according to their abilities, who have high integrity and competence. Swapnil (2008) [22] stated that the quality of human resources in the organization increased or not seen from the relationship of increasing competence and its influence on promotion. [19][22]Employee competence is needed in job promotion so that the duties and functions carried out can be carried out properly, and will generate enthusiasm from employees.

Comparing the influence of politics (X1) with competence (X2) on the promotion of local government, the political aspects have a higher influence according to the regression equation $\breve{Y}=0.518+0.511(\mathrm{X} 1)+0.420(\mathrm{X} 2)+\mathrm{e}$. Political aspects and aspects of competency together contribute $53 \%$ to job promotion in the local government bureaucracy $(\mathrm{R} 2=0.529)$. The fact that political interests often dominate the process of promotion of structural officials in the local government. Assessing the dominant influence of political aspects on job promotion according to Gives conception as an aspirational relationship, the more politicized a bureaucracy is the more comparative a person is appointed (promoted). This means that political assessment is far more strategic than the aspect of competence in determining who is eligible to be promoted. The dominance of political officials in determining career officials is a dilemma for the bureaucratic apparatus itself Kumorotomo. This is because on the one hand the apparatus is an employee who serves the interests of society so that he should be neutral. On the other hand, the closeness of regional staff with the authorities also determines its position in the existing staffing structure. Law Number 9 of 2015 concerning regional government authorizes broad regional heads as officials of staffing. This makes regional heads have prerogative rights in the recruitment, placement and transfer of echelon II and III structural officials. This prerogative right becomes a reference for the politicization of structural officials because promotion or mutation of career officials is carried out in accordance with the wishes of the regional head.

The promotion system is certainly expected to get employees who have high competence and high integrity, so they can carry out their duties well. On the other hand, the existence of demands to accommodate supporters in the election of political officials in the region (Regent / mayor) is a patronage in promotion cannot be avoided, so it requires efforts to maintain both systems, namely the merit system and the patronage system without ignoring the government's vision and mission. Allison in Smith suggests that rulers who have the highest authority determine or influence the bureaucracy and in making decisions there is a game of bidding.[23] Furthermore according to Wilson in bureaucratic behavior tends to be purposive precisely motivated by goals and targets, in this case the power base. Local governments still have difficulty applying the rules of merit system in the procedures for appointing officers in structural positions because they still tend to be formality because the dominant ones are political interests. 


\section{CONCLUSION}

Competence and politics influence on job promotion in the local government bureaucracy, the influence of competence on promotion is dominated by the dimensions of knowledge, and skills. While the political influence on promotion is dominated by the dimension of leadership power and the distribution of positions controlled by the leadership.Comparing the influence of politicsal politics (X1) with competence (X2) on the promotion of local government, the political aspects have a higher influence according to the regression equation $=0.518+0.511(\mathrm{X} 1)+0.420(\mathrm{X} 2)+\mathrm{e}$. This fact shows that political interests often dominate the process of promotion of structural officials in the local government. This means that the promotion system in the local government bureaucracy is interpreted as a merit system-based promotion with political criteria, meaning that there are other criteria besides merit system, namely patron-client criteria. Bureaucratic politicization occurs because the interests of political officials maintain power and career officials to maintain office.

\section{ACKNOWLEDGMENT}

I thanks the the institude for reseach and faculty of social science (FIS) Universitas Negeri Makassar so that the research can be done well as expected.

\section{REFERENCES}

[1] D. J. Provan, S. W. A. Dekker, and A. J. Rae, "Bureaucracy, influence and beliefs: A literature review of the factors shaping the role of a safety professional," Saf. Sci., vol. 98, pp. 98-112, 2017.

[2] Y. Yusran, M. A. K. Sahide, S. Supratman, A. Sabar, M. Krott, and L. Giessen, "The empirical visibility of land use conflicts: From latent to manifest conflict through law enforcement in a national park in Indonesia," Land use policy, vol. 62, pp. 302-315, 2017.

[3] S. A. Silva, H. Carvalho, M. J. Oliveira, T. Fialho, C. Guedes Soares, and C. Jacinto, "Organizational practices for learning with work accidents throughout their information cycle," Saf. Sci., vol. 99, pp. 102-114, 2017

[4] M. Y. Lee and A. C. Edmondson, "Self-managing organizations: Exploring the limits of less-hierarchical organizing," Res. Organ. Behav., vol. 37, pp. 35-58, 2017.

[5] J. Brix, "Exploring knowledge creation processes as a source of organizational learning: A longitudinal case study of a public innovation project," Scand. J. Manag., vol. 33, no. 2, pp. 113-127, 2017.

[6] J. Hartley, J. Alford, O. Hughes, and S. Yates, "Public value and political astuteness in the work of public managers: The art of the possible," Public Adm., vol. 93, no. 1, pp. 195-211, 2015.

[7] P. Block, The empowered manager: Positive political skills at work John Wiley \& Sons, 2016.

[8] P. Healey, G. Cars, A. Madanipour, and C. De Magalhaes, "Transforming governance, institutionalist analysis and institutional capacity," in Urban governance, institutional capacity and social milieux, Routledge, 2017, pp. 20-42.

[9] J. Jiang, "Making Bureaucracy Work: Patronage Networks, Performance Incentives, and Economic Development in China," 2017.

[10] R. L. Daft, Organization theory and design. Cengage learning, 2015.

[11] J. Rohr, Ethics for bureaucrats: An essay on law and values. Routledge, 2017.

[12] B. Purwoko, "Bureaucracy and the Politics of Identity: A Study on the Influence of Ethnicity on the Bureaucrat Recruitment Process in Sorong Selatan Regency, West Papua, Indonesia," Indones. J. Gov. Polit., vol. 7, no. 4, 2016.

[13] M. Wigell, "Political Effects of Welfare Pluralism: Comparative Evidence from Argentina and Chile," World Dev., vol. 95, pp. 2742, 2017.

[14] M. Eshbaugh-Soha, "Presidential rhetoric, agency turnover, and the importance of salience to bureaucratic leadership," Soc. Sci. J., vol.
54, no. 2, pp. 206-215, 2017

[15] C. Leong and N. Qian, "Ambiguity, bureaucracy and certainty: The ABCs of enabling water self-sufficiency," Policy Soc., vol. 35, no. 2, pp. 165-178, 2016.

[16] M. S. Grindle, Politics and policy implementation in the Third World, vol. 4880. Princeton University Press, 2017.

[17] A. Yamin, M. A. Nasution, and H. Kusmanto, "Strengthening Local Bureaucracy. Recruitment Model of Bureaucracy Structural Officials," Acad. J. Econ. Stud., vol. 4, no. 2, pp. 26-36, 2018.

[18] M.-C. Flubacher, A. Duchêne, and R. Coray, "The Politics of Investment and Employability in the Public Employment Service," in Language Investment and Employability, Springer, 2018, pp. 3354.

[19] A.-K. Ward and E. C. Ravlin, "Building influence as an outsider: A theoretical approach to cross-cultural impression management," Hum. Resour. Manag. Rev., vol. 27, no. 3, pp. 491-506, 2017.

[20] N. Batarlienè, K. Čižiūnienè, K. Vaičiūtè, I. Šapalaite, and A. Jarašñnienè, "The Impact of Human Resource Management on the Competitiveness of Transport Companies," Procedia Eng., vol. 187, pp. 110-116, 2017.

[21] A. La Rocca, A. Perna, I. Snehota, and F. Ciabuschi, "The role of supplier relationships in the development of new business ventures," Ind. Mark. Manag., 2017.

[22] M.-S. Ramírez-Montoya, J. Mena, and J. A. Rodríguez-Arroyo, "Inservice teachers' self-perceptions of digital competence and OER use as determined by a XMOOC training course," Comput. Human Behav., vol. 77, pp. 356-364, 2017.

[23] N. Charron, C. Dahlström, M. Fazekas, and V. Lapuente, "Careers, Connections, and Corruption Risks: Investigating the impact of bureaucratic meritocracy on public procurement processes," J. Polit., vol. 79, no. 1, pp. 89-104, 2017. 